\title{
Endosialin: molecular and functional links to tumor angiogenesis
}

\author{
Minireview
}

S. KONTSEKOVA ${ }^{1}$, K. POLCICOVA ${ }^{1}$, M. TAKACOVA ${ }^{1,2}$, S. PASTOREKOVA ${ }^{1,2, *}$

${ }^{1}$ Department of Molecular Medicine, Institute of Virology, Slovak Academy of Sciences, Dubravska cesta 9, 84505 Bratislava, Slovak Republic; ${ }^{2}$ Masaryk Memorial Cancer Institute, RECAMO, Zluty kopec 7, 65653 Brno, Czech Republic

${ }^{*}$ Correspondence: silvia.pastorekova@savba.sk

Received September 7, 2015 / Accepted October 4, 2015

\begin{abstract}
Endosialin, alternatively named tumor endothelial marker 1 (TEM1) or CD248, is a bulk transmembrane glycoprotein expressed both in developing and adult tissues undergoing active physiological or pathological angiogenesis. Endosialin is often overexpressed in tumors, particularly in stromal cells and in vessels-covering pericytes, and its transcription is induced by hypoxia via HIF-2 transcription factor. Based on the expression pattern, molecular characteristics and phenotypes of genetic models, endosialin has been proposed to function as a receptor implicated in sprouting angiogenesis, vasculogenesis and/or pruning of vessels. Here we provide an overview of the recent knowledge linking endosialin to diverse aspects of angiogenesis. Based on data-mining, our experimental data and available literature, we suggest that endosialin cross-talks with both pro- and anti-angiogenic signals and ECM components, and participates in dynamic vascular remodeling, which facilitates tumor growth. Tumor-selective targeting of endosialin may therefore contribute to improvement of existing anti-angiogenic therapies.
\end{abstract}

Key words: endosialin, angiogenesis, pericytes, extracellular matrix, cancer

Endosialin, also designated tumor endothelial marker (TEM1) or CD248, was first identified as an antigen associated with tumor endothelium $[1,2]$ and its enhanced expression was found in blood vessels of various tumors [3]. In addition, endosialin was identified in cultured human fibroblasts and neuroblastoma cell lines [1]. In contrast, normal healthy blood vessels of adult individuals, as well as other tissues, display weak endosialin expression $[1,4,5]$. Subsequent studies have shown that endosialin is a marker of activated mesenchymal cells forming the stroma of human tumors and is likely to influence their migration and proliferation [3].

The precise role of endosialin in the organism is not fully understood, however, based on its expression pattern, it is considered for a potential target in anti-cancer therapy.

\section{Molecular characteristics of endosialin}

The intronless human gene for endosialin is localized on the long arm of the chromosome 11 (11q13). Its open reading frame is $2274 \mathrm{bp}$ long and encodes a type I transmembrane protein of 757 amino acids [2]. In silico analysis identified endosialin as a precursor sequence for the eukaryotic cell surface protein, which likely underwent a process of domain shuffling during the evolution. The structure of endosialin suggests that it is a C-type lectin-like protein, with the structure comprising several segments of different functions. The $\mathrm{N}$-terminal portion (aa 1-20) of the protein corresponds to the signal peptide required for the transport into the endoplasmic reticulum. The signal peptide is followed by five globular extracellular domains (aa 30-360) and a C-terminal segment (aa 361-757) [2]. The extracellular segments were identified as a C-type lectin domain (CTLD, aa 29-157), a Sushi/SCR/CCP domain (aa 176-230) and three EGF-like domains (aa 235-350). The latter two EGF domains may be $\mathrm{Ca}^{2+}$-binding. The $\mathrm{C}$-terminal half of the protein comprises three domains: a low-complexity region - the sialomucinlike sequence (aa 361-685), a hydrophobic transmembrane region (aa 686-706) and, finally, a proline-rich short cy- 
toplasmic tail (aa 707-757) [2]. The cytoplasmic tail of endosialin contains a putative PDZ binding domain [6]. $\mathrm{PDZ}$ domains are involved in a number of protein-protein interactions and act as adaptor molecules that hold receptor and signaling molecules in large complexes and participate in signaling events [7].

The structure of endosialin is similar to at least two other proteins, thrombomodulin (CD141) and C1qRp (CD93) protein $[2,8,9]$. The $\mathrm{N}$-terminal half of the endosialin (aa 1-360) has 39\% sequence homology with the precursor protein of the human thrombomodulin (CD141) - a receptor responsible for blood coagulation. In addition, this part shares 33\% homology with the human complement receptor C1qRp. The homologous region comprises the CTLD domain, Sushi domain and EGF domain. There are three EGF repeats in the endosialin, six in thrombomodulin and five in the $\mathrm{C} 1 \mathrm{qRp}$ receptor $[2,8,9]$. There is also some similarity between ClqRp receptor and endosialin in the cytoplasmic tail; the $\mathrm{ClqRp}$ receptor was shown to contain a $\mathrm{PDZ}$ domain, which is involved in the interaction with GIPC protein and this interaction seems to be involved in the modulation of phagocytosis [10]. Despite the relatively low sequence identity between the three orthologs, the positions of the cysteine residues, which are critical for the formation of the disulfide bridges, are conserved [2]. Based on the structural similarity of these three proteins, it was suggested that endosialin plays the role of a receptor [11].

Endosialin is highly O-glycosylated in most human cell types and is sensitive to O-sialoglycoprotein endopeptidase, which suggests that it is a sialomucin-like molecule [11]. The presence of O-glycosylation and sialic acid was shown by Rettig et al. [1], who identified three forms of endosialin. The mature form of the protein with MW of $165 \mathrm{kDa}$ (p165) can be stripped of the sialic acid to yield a partially glycosylated form with $\mathrm{MW}$ of $120 \mathrm{kDa}$ (p120). The third form, the core protein with no posttranslational modifications, has the molecular weight of $80.9 \mathrm{kDa}$. The putative glycosylation sites were identified in the CTLD domain on the Thr60 and in the series of Ser/Thr residues in the region of aa 400-669 [2].

\section{Endosialin expression in tissues}

The first studies identified endosialin as a marker of tumor endothelium [1]. It was later shown, however, that endosialin is primarily expressed by fibroblasts, pericytes and smooth muscle cells, but not by human umbilical vein cells (HUVEC), primary blood vessel endothelial cells, cells of lymphatic endothelium or epithelial cells $[3,12]$.

MacFadyen and colleagues [12] have characterized endosialin as a marker of stromal fibroblasts, cells that are responsible for the synthesis and remodeling of extracellular matrix. The expression of endosialin was later detected in pericytes of central nervous system in mouse embryos, as well as in pericytes and fibroblasts of mouse lymphoid tissue [13, 14]. Immunohistochemical analysis showed expression of endosialin mostly in cells of mesenchymal origin, while in cells of healthy tissues only low level of endosialin was found. Endosialin expression was detected also in mesenchymal stem cells originating from bone marrow [15].

Further confirmation that endosialin is not a marker of cancer cells, but is expressed by supportive tissue came from the comparison of endosialin expression in various tumorassociated cells and tumor cell lines using RT-PCR. High level of endosialin expression was detected in different parts of tumor-surrounding stroma both in vivo and in vitro. With only few exceptions, endosialin is not expressed in cancer cells [3].

The colocalization of endosialin and the marker of pericytes NG2 by means of immunohistochemistry and confocal microscopy proved that endosialin expression is enhanced in tumor-associated pericytes [16]. Endosialin is considered a marker of pericytes in glioma vasculature, as it is not detected in normal brain tissue. Glioblastomas, the most aggressive types of gliomas, express endosialin in high levels [17]. In addition, the expression of endosialin was detected also in vasculature and stroma of metastatic brain lesions [18]. Moreover, the expression of endosialin was detected on the cellular surfaces in several neuroblastoma cell lines $[1,19]$.

Similar to glioblastomas, the endosialin expression in carcinomas is mostly stromal and perivascular. In sarcomas, endosialin may be expressed by some malignant cells, perivascular cells and cells of tumor stroma. Newer studies have shown that endosialin is expressed in a specific type of tumor cells, which have the characteristics of stem cells and a highly aggressive phenotype. These cells were designated side populations (SP) and were identified in sarcomas and carcinomas [20]. The tumor cell lines of epithelial origin, e.g. cells derived from cervical carcinoma (HeLa) or fibrosarcoma (e.g. HT1080), do not express endosialin $[1,3,19]$.

In nonpathological conditions, the endosialin expression seems to be dynamically regulated during the embryonic development of CNS, spleen, thymus and lymphatic nodes, and the expression ceases during the postnatal development $[13,14]$. In a healthy adult organism, endosialin is expressed in tissues in need of active angiogenesis, e.g. in corpus luteum, granular tissue, during wound healing, or in the stromal compartment of endometrium $[4,21,22]$, and on the surface of naïve CD8+ T-lymphocytes, as it probably negatively regulates their proliferation, ensuring they remain in the quiescent state [23].

Genevestigator analysis-based concise overview of the expression pattern of endosialin in normal and tumor tissues is shown on Fig. 1. Since this analysis is based on RNA microarray metadata [24], it generally exhibits overall medium transcription levels in various tissue types (Fig. 1A). However, closer look into the particular cell types shows high expression in cells of mesodermal origin (like bronchial smooth muscle cells, lung or dermal fibroblasts, and breast stromal cells) but not in epithelial cells, in accordance with the data from immunohistochemistry (Fig. 1B). 
A

A
Stomach
Small intestine
Colon
Pancreas
Bronchus and lung
Bone
Skin
Breast
Cervix uteri
Ovary
Prostate
Kidney

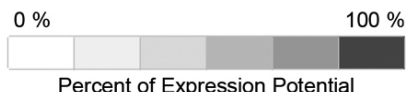

B

respiratory system cell bronchial epithelial cell bronchial smooth muscle cell lung fibroblast myofibroblasts large airway epithelial cell small airway epithelial cell cuboidal elveolar type 2 cell (AT2) tracheal epitelial cell

number of samples

1332

632

6

18

48

62

516

6

skin cell

basal epidermis cell dermal fibroblast dermal papilla cell epidermal keratinocyte Langerhans cell melanocyte reticular dermis cell suprabasal epidermis cell

breast cell breast epithelial cell breast stromal cell
190

3

Figure 1. (A) Overview of endosialin expression in normal and corresponding tumor human tissues according to data from Genevestigator analysis. Lighter shades mean lower endosialin expression whereas darker shades mean higher endosialin expression. Bronchus and lung, skin, and breast normal tissues as well as pancreatic tumors are characterized by heterogeneous expression of endosialin (shown by light/dark boxes). (B) For tissues with heterogeneous expression, more detailed expression pattern associated with specific types of cells was extracted from Genevestigator analysis output.

\section{Regulation of endosialin expression}

Both pericytes and stromal fibroblasts play important roles in tumor angiogenesis through paracrine signaling, ECM remodeling and cell-cell communication with endothelium. Because angiogenesis in growing tumors and in developing embryo is stimulated by low oxygenation, it was suggested that hypoxia influences endosialin expression. This idea was confirmed by experiments on human cell lines expressing endosialin, namely placental fibroblasts FIB-3 and glioblastoma cell line 42-MGBA. An elevated level of endosialin was detected following $24 \mathrm{~h}$ incubation under hypoxic conditions $\left(2 \% \mathrm{O}_{2}\right)$ in comparison with normoxic cells [25]. Subsequent in silico analysis of endosialin gene and its promoter confirmed the presence of several hypoxia-responsive elements (HRE) in the promoter region of endosialin. The co-transfection experiments in HeLa cells using endosialin promoter and an expression vector encoding for HIF-1 $\alpha$ or HIF-2 $\alpha$ showed that HIF-2 $\alpha$ binds to the endosialin promoter at the position -976/-969 upstream of the transcription start and has a significant effect on its activity. HIF-1 $1 \alpha$, however, is also involved in the regulation of endosialin expression under hypoxic conditions, possibly through cooperation with other transcription factors [25].

A small subgroup of genes regulated by HIF-2 $\alpha$ contains in the promoter region at least one HRE close to the binding site of the ETS transcription factor (EBS, ETS binding site), allowing thus for interaction between HIF-2 $\alpha$ and a member of the ETS transcription factor family [26]. Two EBS were identified in the promoter region of endosialin, both of which are located less than 80 bp downstream of HRE -976/-969, at the positions $-935 /-919$ and $-907 /-891$. Subsequently, an interaction was confirmed between the ETS family protein Ets-1 and HIF- $2 \alpha$ in the regulation of endosialin expression [25].

The expression of endosialin in cell culture is influenced by the cell density in mouse-cell models expressing endosialin [5]. Ohradanova et al. confirmed the density effect in human cells and found that it may be partially mediated by pericellular hypoxia, which occurs in cells growing to high density $[25,27]$. The regulation of endosialin expression in densely growing cells is likely mediated by the transcription factor SP1, as its inhibition by mithramycin A decreases the densityinduced expression of endosialin. The cell density can affect the endosialin expression under both normoxic and hypoxic conditions [25].

As evident from the above paragraphs, the human endosialin promoter has been explored only in one published study, so there remains a lot of space for further investigations. In silico analysis using MatInspector shows presence of several interesting binding sites for important transcription factors that participate in oncogenic signaling and/or ang- 


\begin{abstract}
$-500$
OCT1

MAZ/SP1 KROX/SP1

HES 1

GAGTGCACTC TTGCATGGGG TTGGGGGTGG GGGAGGCGCA TGCGCGCGTC TGTGGGGCAA

NFkB HES1

GAAAgGAGTG GGCATGAgGg TGTTCCCGTG CATGgCGAGC AgCTGGGCTG AGACTGCTCC

STAT5A

CGGGTGTGAT GGgGCTGCTG TGTCCAGATT TGGGTCTCTG AGTCTCTGGG AAGCGACCTC

ACCCCACAGC CCCGAGCCCC AACTTGAGGG TCACAGAGCT CGGCAGGCAG GCTTTTCCCA

SP1

CREB

MAZ

CCCCCTGACT CTCAGCCCCA TGGGGCCTGG GGCAGCCGTC AACTGCGCCT TCTCCCCTCC

EGR1/SP1 EGR1

MAZ SP1/MAZ

ETS 1

TCCGCCCCCA ACCTTAGAGC CCCCCACCCC ACTGCTTCCT

GCTCTAGCGG CCCCCGGGGA

AGAGGGAGCA GGGAGCTGGC AGCCGCCCCA GCCCACTCCT TACAAGGCCT GAGCCCGGCC

SP1/EGR1 SP1 SP1 KROX/MIZ

CCAGGCCCGC CCCCGGCCCG CCCGCAGGAG GCCCCAGGCC CTCCCCCTGT CAAGAGCTGC $\mathrm{SP}^{-1}$ Transcription start CGCCAGCCCG GGGCCGGACC AGTCCGGGGG CATCGCGATG CTGCTGCGCC TGTTGCTGGC

CTGGGCGGCC GCAGGGCCCA CACTGGGCCA GGACCCCTGG GCTGCTGAGC CCCGTGCCGC
\end{abstract}

\begin{abstract}
Figure 2. Nucleotide sequence of endosialin promoter with potential binding sites for transcription factors. Detailed analysis of 601 bp proximal promoter sequence was performed with MatInspector. Transcription factors were selected according to the matrix similarity and only those with score higher than 0.85 were taken into account. Arrow indicates the position of transcription start site. Transcription factors, which were already shown to regulate endosialin promoter activity [24], are highlighted on the black background.
\end{abstract}

iogenesis [28], including HES1 (activated by Notch), MAZ (MYC-associated), CREB, EGR1 etc. (Fig. 2). Interestingly, our recent unpublished experiments with HeLa cells stably transfected with endosialin promoter-driven luciferase revealed that endosialin transcription can be induced by several pro-angiogenic growth factors, including EGF, PDGF-BB and basic FGF, and that the transactivation is further increased by hypoxia and serum starvation, conditions typical for tumor microenvironment. However, transcription factors and their binding sites mediating these effects remain to be dissected. Thus, functional studies of regulatory elements acting in the context of endosialin promoter are clearly warranted to better understand conditions and events behind the endosialin expression. Even less is known about the endosialin regulation at post-transcriptional and posttranslational levels.

\section{Functional implications of endosialin}

Functions of proteins are often deduced from their molecular structure. The extracellular domain of endosialin with its C-type lectin domain and three EGF repeats is similar to selectins and may therefore function in cell-cell interactions $[29,30]$. In contrast, the cytoplasmic tail contains a PDZ domain and is presumably responsible for the transduction of the extracellular signals into the cell $[2,6]$. Transgenic animals expressing endosialin with the deletion of the cytoplasmic tail develop significantly smaller tumors following subcutaneous injection of fibrosarcoma cells T241 than the wild type animals [6]. Thus, the cytoplasmic tail of endosialin seems to be important for the growth of some tumor types.

Based on the endosialin expression in embryonic and tumor tissues, where the formation and reorganization of blood vessels occurs at a high rate, endosialin may be involved in angiogenesis and may thus represent an important target of antiangiogenic tumor therapy $[1,5]$. However, in spite of the original expectations that endosialin plays a role in the embryonic development [5], the development of both wild type (WT) and knock-out (KO) animals is comparable. The $\mathrm{KO}$ animals lacking endosialin have fully developed and functional vasculature and normal wound healing. Following subcutaneous implantation, the tumor growth is normal as well. In contrast, tumors implanted abdominally grow 
significantly slower in KO mice than in the WT animals, the number of small blood vessels is increased and the invasiveness of the tumors is decreased [31]. Maia and colleagues [6] obtained similar result in $\mathrm{KO}$ mice with a different genetic background and different tumor-inducing cells. As the growth-reduction was detected in only certain tumor tissue context, it raises the question of the influence of the factors in the tumor microenvironment. Actually, endosialin is a cellsurface protein with a bulk extracellular domain that can interact with the components of extracellular matrix (ECM) [32], namely with collagen types I and IV, and fibronectin via the CTLD domain. In addition, expression of endosialin leads to enhanced adhesion of cells to fibronectin as well as to increased cell migration through matrigel in comparison to cells not expressing endosialin. Enhanced cell migration may be the result of the increased activity of matrix metalloproteinase 9, which is expressed to higher levels in the presence of endosialin [32]. Loss-of-function experiments showed that the decrease of the endosialin expression following siRNA treatment is accompanied by the decrease of fibroblasts' migration and proliferation [3].

Endosialin is primarily expressed by the mural cells of blood vessels, i.e. pericytes and vascular smooth muscle cells (vSMC) $[3,12]$. Pericytes communicate with endothelial cells through common basement membrane and via paracrine cellcell signaling. These mutual interactions between pericytes and endothelial cells are required for survival and maturation of vessels [33]. The proliferation of pericytes is highly dependent on the presence of PDGF-BB, which is secreted by endothelial cells. This growth factor binds to the receptor PDGFR- $\beta$, which is expressed on the surface of pericytes. Silencing of endosialin expression in the presence of PDGF$\mathrm{BB}$ results in impaired pericyte proliferation; the presence/ absence of endosialin, however, has no effect on the expression of PDGFR- $\beta$ or its autophosphorylation after the interaction with the ligand. Instead, it seems that the signalization affecting pericyte proliferation is regulated by endosialin by means of regulation of PDGFR- $\beta$-induced phosphorylation of the MAP kinase ERK1/2. One of the first downstream components of this signaling pathway is the transcription factor $c$-fos, which is involved in the proliferation of pericytes [34]. Since proliferation of pericytes is associated with newly forming vessels and is important for sprouting angiogenesis/vasculogenesis, these data support a role for endosialin in these pro-angiogenic processes. In line with this assumption, endosialin-deficient mice show a PDGFR- $\beta$-dependent defect in capillary sprouting during skeletal angiogenesis [35].

Nevertheless, further functional studies of endosialin using a postnatal retinal model of endosialin-lacking $\mathrm{KO}$ mice [30] suggest that, in this model, loss of endosialin has no major effect on vascular sprouting and pericytes recruitment, but is rather associated with selective vessel regression, leading to increased density of the vasculature [42]. Moreover, endosialin binding to endothelium-associated basement membrane components induces endothelial apoptosis and detachment.
These data suggest that endosialin participates in vascular patterning, which is critical for optimal blood feeding of the tissue as discussed below. Actually, it is now increasingly accepted that tumor growth depends on properly functioning vascular network, which has to be dense enough to supply oxygen and nutrients to all tumor areas, with lumens able to lead the blood through vessels, with optimal pericytes coverage to be non-leaky but flexible to react by sprouting to requirements of expanding tumor mass, and at the same time lacking excessive shunts leading the blood through short paths and generating ischemia and hypoxia [36]. Thus, angiogenesis is now perceived not only as the phenomenon of vessel formation, but also as the process of their remodeling and pruning. Indeed, animal models indicate that endosialin may contribute to different facets of angiogenesis, and this view is supported also by the molecular studies as described below.

Additional experiments aiming to uncover endosialin function showed that this protein is also a marker of mesenchymal stem cells [15] and is a negative regulator of bone formation in mice [37]. Endosialin knock-out mice had higher bone mass than the wild type animals. This finding may be helpful in search for the treatment of rheumatoid arthritis. Recently, endosialin was found to play a role in fibrogenesis and hepatocyte proliferation during liver injury via a PDGF-related mechanism $[38,39]$.

\section{Downstream effects of endosialin}

Another insight into the possible function of endosialin in angiogenesis was obtained through analyzing effects of its overexpression in cancer HeLa cells that do not express endogenous endosialin. The cells were transfected with the phCMV1-TEM1 plasmid carrying the endosialin gene or its deletion variants as described earlier [25,40]. Relative levels of genes implicated in angiogenesis were analyzed using the Human Angiogenesis RT2 Profiler (Qiagen) according to the manufacturer's instructions. Expression of endosialin in HeLa cells led to the transcriptional up-regulation of genes mostly involved in cell-cell communication, adhesion and motility (Fig. 3). The group of most induced genes consists predominantly of cytokines and chemokines (such as CCL2, IL-6, IL-8), angiogenic growth factors and receptors (angiopoetin 2, ANGPT-like 3 and 4, IL-1 $\beta$, EGF, TGF- $\beta$ receptor, Ephrin-A3, Neuropilin 1), and ECM components (COL1A8). The list includes also the Notch4 receptor, which is normally present on vascular endothelial cells and participates in control of vascular sprouting and branching [41]. The genes down-regulated in the presence of endosialin include matrix metallopeptidase 9 and tissue metallopeptidase inhibitor TIMP, both of which were found to be involved in the regulation of angiogenesis $[42,43]$. Interestingly, one of the downregulated genes codes for the ligand of the Notch4 receptor, protein Jagged-1, which was proposed to stimulate angiogenesis [44]. Several additional angiogenic modulators also show decreased expression, including TGFA, FGF1, 
A

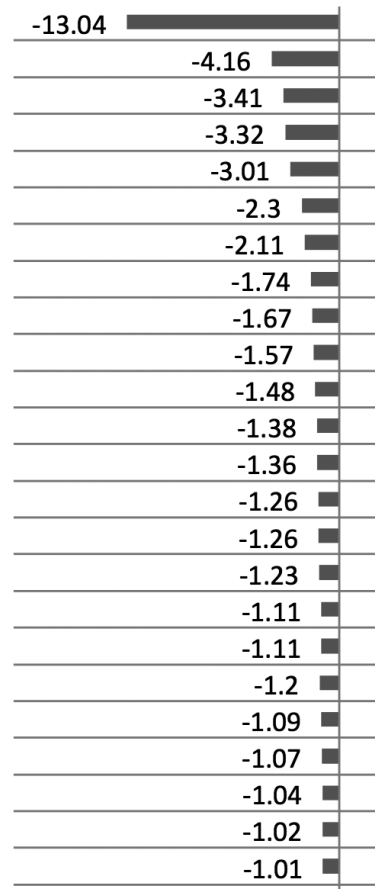

B

\begin{tabular}{|c|c|c|}
\hline TGFA & 1.36 & TGFB1 \\
\hline SERPINF1 & 1.36 & CXCL3 \\
\hline THBS2 & 1.43 & IL8 \\
\hline JAG1 & 1.45 & ID1 \\
\hline ANPEP & 1.47 & IL1B \\
\hline STAB1 & 1.47 & EGF \\
\hline FGF1 & 1.49 & EPHB4 \\
\hline PECAM1 & 1.78 & FGF2 \\
\hline TIMP1 & 1.81 & TGFBR1 \\
\hline PDGFA & 2 & THBS1 \\
\hline COL4A3 & 2.1 & IFNA1 \\
\hline PLAU & 2.09 & ANGPTL3 \\
\hline NRP2 & 2.45 & TNFAIP2 \\
\hline FIGF & 2.57 & AKT1 \\
\hline VEGFA & 3.38 & Notch4 \\
\hline ITGAV & 3.66 & ANGPTL4 \\
\hline HPSE & 3.73 & S1PR1 \\
\hline ENG & 3.85 & EFNA3 \\
\hline TGFB2 & 4.99 & NRP1 \\
\hline HIF1A & 5.28 & PTGS1 \\
\hline MMP9 & 5.72 & IL6 \\
\hline CXCL1 & 20.25 & $\mathrm{CDH} 5$ \\
\hline IGF1 & 20.97 & COL18A1 \\
\hline EFNB2 & 34.78 & \\
\hline
\end{tabular}

Figure 3. Effect of endosialin overexpression on transcription of angiogenesis-related genes evaluated by RNA array analysis. Overexpression of endosialin in HeLa cells stimulates expression of various factors involved in angiogenesis. The graph shows genes downregulated (A) or upregulated (B) in the presence of endosialin.

THSB2, COL4A3, etc). The list of the genes differentially expressed due to endosialin expression contains both proand anti-angiogenic molecules suggesting that endosialin may potentially be involved in diverse, even counteracting aspects of angiogenesis, in accord with the data from studies of genetic animal models.

Not surprisingly, we found that the effects on expression of most genes were mediated by the biggest sialomucine domain (Fig. 4). However, several genes, including Notch4, JAG1, IL6, CHD5, CCL2 and AKT1 remained differentially expressed in the absence of any of the extracellular domains of endosialin. It is thus possible that regulation of these genes depends on the cytoplasmic tail of endosialin, since this is the only domain present in all deletion variants and its importance for the full functioning of the protein was experimentally proven both in vitro and in vivo. Mouse embryonic fibroblasts prepared from animals lacking the cytoplasmic tail of endosialin have significantly reduced transcript levels of PIGF and its receptor as well as of the VEGF receptor 1 [45]. It was also suggested that the cytoplasmic tail of endosialin may transmit signals and link tumor growth to blood vessel density [6].

\section{Genes co-expressed with endosialin}

Information on possible functional aspects of endosialin can be also extracted through data-mining approaches, such as analysis of Genevestigator and GeneFriends databases, which combine results from tens of thousands of microarrays [24, 46]. Searches for genes co-expressed with endosialin in healthy and/or cancerous tissues revealed a spectrum of molecules, expression of which is positively correlated with endosialin expression (Supplemental Table 1). These include mostly components of ECM (such as fibrillar collagens I, III, V, XIII, networking collagen VI, fibrillin, fibulin, vasorin), enzymes involved in ECM stiffness and remodeling (pro-collagen peptidases, LOX and LOX-like1,2, MMP2, MMP14, cathepsin K) as well as growth factors and receptors involved in paracrine signaling, cell-cell or cell-ECM adhesion, migration/invasion (angiopoetin-like 2, integrins, PDGFR- $\beta$, IFGBP4/6). Many of these molecules have been implicated in angiogenesis and/or in epithelial-mesenchymal transition - processes that critically contribute to cancer progression and are strongly affected by ECM composition and dynamics $[47,48,49]$.

\section{Endosialin as a therapeutic target}

All these complex molecular relationships of endosialin and its expression in both physiological and pathological conditions call for very careful design of strategies of its diagnostic and therapeutic targeting. Recent studies propose several approaches including tumor immune-PET applications [50], endosialin-specific DNA vaccination targeting tumor vascula- 
A

\begin{tabular}{|c|c|c|c|c|}
\hline \multirow[t]{2}{*}{ Gene } & \multicolumn{3}{|c|}{$\begin{array}{l}\text { Deleted domain } \\
\text { of endosialin }\end{array}$} & \multirow[t]{2}{*}{ Description / function } \\
\hline & CTDL & EGF & MUC & \\
\hline AKT1 & $\Delta$ & $\Delta$ & $\Delta$ & Protein kinase / signal transduction, survival, proliferation, metabolism \\
\hline CCL2 & $\Delta$ & & $\Delta$ & Chemokine / augments monocyte anti-tumor activity \\
\hline CDH5 & $\Delta$ & & $\Delta$ & $\begin{array}{l}\text { Endothelial cadherin / neovasculogenesis, vascular mimicry, responsive to } \\
\text { hypoxia }\end{array}$ \\
\hline IL6 & $\Delta$ & & $\Delta$ & $\begin{array}{l}\text { Interleukin / paracrine signaling, pro-angiogenic, pro-inflammatory, } \\
\text { responsive to hypoxia }\end{array}$ \\
\hline NOTCH4 & $\Delta$ & & $\Delta$ & $\begin{array}{l}\text { Receptor / signal transduction, stemness, sprouting angiogenesis, } \\
\text { endothelial cell migration and specialization }\end{array}$ \\
\hline JAG1 & & & $\nabla$ & Notch ligand / signal transduction, sprouting angiogenesis, tip cell selection \\
\hline ANGPTL3 & $\Delta$ & & $\approx$ & Growth factor / pro-angiogenic signaling, lipid metabolism \\
\hline ANGPTL4 & $\Delta$ & $\Delta$ & $\approx$ & Growth factor / pro-angiogenic signaling, metabolism, responsive to hypoxia \\
\hline COL18A1 & $\Delta$ & & $\approx$ & ECM component / signaling, adhesion, cleavage produces endostatin \\
\hline EFNA3 & $\Delta$ & & $\approx$ & Receptor kinase / development, signal transduction, angiogenesis \\
\hline IFNA1 & $\Delta$ & & $\approx$ & Interferon / anti-proliferative signaling, regulation of immune defense \\
\hline EGF & $\Delta$ & $\Delta$ & $\approx$ & Growth factor / mitogenic signaling \\
\hline NRP1 & $\Delta$ & $\Delta$ & $\approx$ & Receptor / angiogenesis, cell migration, sequesters VEGF-165 \\
\hline IL1B & $\Delta$ & & $\approx$ & Cytokine / paracrine signaling, pro-angiogenic, pro-inflammatory \\
\hline ANPEP & $\nabla$ & & $\approx$ & Metallopeptidase / development, differentiation, proliferation \\
\hline CXCL3 & $\approx$ & $\Delta$ & $\Delta$ & Chemokine / pro-inflammatory \\
\hline FGF2 & $\approx$ & & $\Delta$ & Growth factor / pro-angiogenic signaling \\
\hline TGFRB1 & $\Delta$ & $\approx$ & $\approx$ & Growth factor receptor / pro-angiogenic signaling, EMT \\
\hline THBS1 & $\Delta$ & $\approx$ & $\approx$ & Adhesion molecule / cell-cell \& cell-ECM interactions, anti-angiogenic \\
\hline COL4A & $r$ & $\sim$ & $\approx$ & $\begin{array}{l}\text { Basement membrane component / angiogenesis, cleavage produces } \\
\text { arresten }\end{array}$ \\
\hline S1PR1 & $\approx$ & $\Delta$ & $\approx$ & Receptor / differentiation of endothelial cells, inhibits sprouting angiogenesis \\
\hline IL8 & $\approx$ & & $\approx$ & Chemokine / paracrine signaling, pro-angiogenic, pro-inflammatory \\
\hline FGF1 & $\approx$ & & $\approx$ & Growth factor / modifier of endothelial cell proliferation and migration \\
\hline SERPINF1 & $\approx$ & & $\approx$ & Peptidase inhibitor / anti-angiogenic \\
\hline THBS2 & $\approx$ & & $\approx$ & $\begin{array}{l}\text { Adhesion molecule / cell-cell \& cell-ECM interactions, anti-angiogenic, } \\
\text { inhibits tumor growth }\end{array}$ \\
\hline STAB1 & $\approx$ & $\approx$ & $\nabla$ & Receptor / angiogenesis, lymphocyte homing, cell adhesion, endocytosis \\
\hline
\end{tabular}

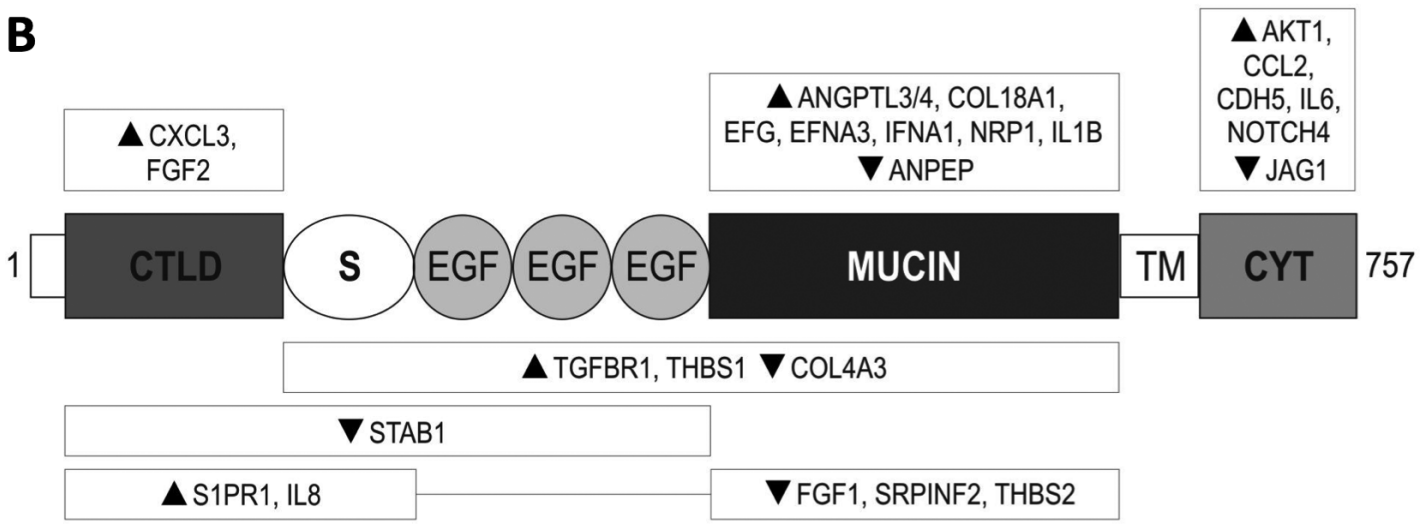

Figure 4. (A) Changes in expression profile of angiogenesis-related transcripts in endosialin deletion variants. Description of genes and functions of encoded proteins was adopted from GeneCards $s^{\star}$, The Human Gene database (www.genecards.org). (B) Domain structure of endosialin and deduced downstream targets of signalling through individual domains. CTLD (C-type lectin domain), S (sushi domain), EGF (epidermal growth factor-like domain), MUCIN (sialomucin domain), TM (transmembrane region), CYT (cytoplasmic domain). 
ture [51], and cytotoxic immunotherapy with anti-endosialin humanized antibody ontuxizumab (MORAb-004) or with antibody-drug conjugate $[52,53]$. Although the efforts towards clinical applications are only in the early stage of pre-clinical and/or clinical development, they show promising results with preliminary observations of antitumor activity, good safety profile and pharmacokinetics [54].

\section{Conclusion}

Recent knowledge related to (i) endosialin expression in tissues undergoing active vessel formation and remodeling, and in cell types participating in these processes, (ii) regulation by hypoxia and growth factors, (iii) downstream effects on cellular expression program typical for diverse aspects of neovascularization and vessel regression, (iv) interactions and co-expressions with ECM components modulating these processes, all-in-all supports the close functional link of endosialin to angiogenesis. However, similarly to the angiogenic process itself, encompassing many seemingly controversial situations, e.g. cell proliferation versus death, vessel sprouting versus regression, lumenization versus shunting, the role of endosialin appears to be rather complex, connected to both pro- and anti-angiogenic steps. This is underlined by the experimental and bioinformatic data on crosstalk of endosialin with molecules that participate in both sides of the dynamic angiogenesis. This suggests that the actual functioning of endosialin is highly context-dependent and its deeper understanding will require thinking in terms of cooperation with other molecules in the concrete microenvironmental conditions. Endosialin is definitely worth further investigations in order to build rationale for its effective anti-cancer therapeutic targeting.

Supplementary information is available in the online version of the paper.

Acknowledgements: This work was supported by European Regional Development Fund and the State Budget of the Slovak Republic (Biomed project ITMS 26240220087) and by the project MEYS - NPS I - LO1413.

\section{References}

[1] RETTIG WJ, GARIN-CHESA P, HEALEY JH, SU SL, JAFFE EA, OLD LJ. Identification of endosialin, a cell surface glycoprotein of vascular endothelial cells in human cancer. Proc Natl Acad Sci U S A 1992; 89: 10832-10836. http://dx.doi. org/10.1073/pnas.89.22.10832

[2] CHRISTIAN S, AHORN H, KOEHLER A, EISENHABER F, RODI HP et al. Molecular cloning and characterization of endosialin, a C-type lectin-like cell surface receptor of tumor endothelium. J Biol Chem 2001; 276: 7408-7414. http://dx.doi. org/10.1074/jbc.M009604200

[3] CHRISTIAN S, WINKLER R, HELFRICH I, BOOS AM, BESEMFELDER E et al. Endosialin (Tem1) is a marker of tumor-associated myofibroblasts and tumor vessel-associated mural cells. Am J Pathol 2008; 172: 486-494. http://dx.doi. org/10.2353/ajpath.2008.070623

[4] CARSON-WALTER EB, WATKINS DN, NANDA A, VOGELSTEIN B, KINZLER KW ETAL. Cell surface tumor endothelial markers are conserved in mice and humans. Cancer Res 2001; 61: 6649-6655.

[5] OPAVSKY R, HAVIERNIK P, JURKOVICOVA D, GARIN MT, COPELAND NG et al. Molecular characterization of the mouse Tem $1 /$ endosialin gene regulated by cell density in vitro and expressed in normal tissues in vivo. J Biol Chem 2001; 276: 38795-38807. http://dx.doi.org/10.1074/jbc.M105241200

[6] MAIA M, DEVRIESE A, JANSSENS T, MOONS M, LORIES RJ et al. CD248 facilitates tumor growth via its cytoplasmic domain. BMC Cancer 2011; 11: 162. http://dx.doi. org/10.1186/1471-2407-11-162

[7] GARDIOL D. PDZ-containing proteins as targets in human pathologies. FEBS J. 2012; 279: 3529. http://dx.doi. org/10.1111/j.1742-4658.2012.08685.x

[8] SUZUKI K, KUSUMOTO H, DEYASHIKI Y, NISHIOKA J, MARUYAMA I et al. Structure and expression of human thrombomodulin, a thrombin receptor on endothelium acting as a cofactor for protein C activation. EMBO J 1987; 6: 1891-1897.

[9] NEPOMUCENO RR, HENSCHEN-EDMAN AH, BURGESS WH, TENNER AJ. cDNA cloning and primary structure analysis of $\mathrm{C} 1 \mathrm{qR}(\mathrm{P})$, the human $\mathrm{C} 1 \mathrm{q} / \mathrm{MBL} / \mathrm{SPA}$ receptor that mediates enhanced phagocytosis in vitro. Immunity 1997; 6: 119-129. http://dx.doi.org/10.1016/S1074-7613(00)80419-7

[10] BOHLSON SS, ZHANG M, ORTIZ CE, TENNER AJ. CD93 interacts with the PDZ domain-containing adaptor protein GIPC: implications in the modulation of phagocytosis. Journal of leukocyte biology 2005; 77: 80-89.

[11] TEICHER BA. Newer vascular targets: endosialin. Int J Oncol 2007; 30: 305-312.

[12] MACFADYEN JR, HAWORTH O, ROBERSTON D, HARDIE D, WEBSTER MT et al. Endosialin (TEM1, CD248) is a marker of stromal fibroblasts and is not selectively expressed on tumour endothelium. FEBS Lett 2005; 579: 2569-2575. http://dx.doi.org/10.1016/j.febslet.2005.03.071

[13] MACFADYEN J, SAVAGE K, WIENKE D, ISACKE CM. Endosialin is expressed on stromal fibroblasts and CNS pericytes in mouse embryos and is downregulated during development. Gene Expr Patterns 2007; 7: 363-369. http:// dx.doi.org/10.1016/j.modgep.2006.07.006

[14] LAX S, HOU TZ, JENKINSON E, SALMON M, MACFADYEN JR et al. CD248/Endosialin is dynamically expressed on a subset of stromal cells during lymphoid tissue development, splenic remodeling and repair. FEBS Lett 2007; 581: 3550-3556. http://dx.doi.org/10.1016/j.febslet.2007.06.063

[15] BAGLEY RG, WEBER W, ROULEAU C, YAO M, HONMA $\mathrm{N}$ et al. Human mesenchymal stem cells from bone marrow express tumor endothelial and stromal markers. Int J Oncol 2009; 34: 619-627. http://dx.doi.org/10.3892/ijo 00000187

[16] VIRGINTINO D, GIROLAMO F, ERREDE M, CAPOBIANCO C, ROBERTSON D et al. An intimate interplay 
between precocious, migrating pericytes and endothelial cells governs human fetal brain angiogenesis. Angiogenesis 2007; 10: 35-45. http://dx.doi.org/10.1007/s10456-006-9061-x

[17] SIMONAVICIUS N, ROBERTSON D, BAX DA, JONES C, HUIJBERS IJ et al. Endosialin (CD248) is a marker of tumorassociated pericytes in high-grade glioma. Mod Pathol 2008; 21: 308-315. http://dx.doi.org/10.1038/modpathol.3801006

[18] CARSON-WALTER EB, WINANS BN, WHITEMAN MC, LIU Y, JARVELA S et al. Characterization of TEM1/endosialin in human and murine brain tumors. BMC Cancer 2009; 9: 417. http://dx.doi.org/10.1186/1471-2407-9-417

[19] ROULEAU C, CURIEL M, WEBER W, SMALE R, KURTZBERG L et al. Endosialin protein expression and therapeutic target potential in human solid tumors: sarcoma versus carcinoma. Clin Cancer Res 2008; 14: 7223-7236. http://dx.doi. org/10.1158/1078-0432.CCR-08-0499

[20] ROULEAU C, SANCHO J, CAMPOS-RIVERA J, TEICHER BA. Endosialin expression in side populations in human sarcoma cell lines. Oncol Lett 2012; 3: 325-329.

[21] ST CROIX B, RAGO C, VELCULESCU V, TRAVERSO G, ROMANS KE et al. Genes expressed in human tumor endothelium. Science 2000; 289: 1197-202. http://dx.doi. org/10.1126/science.289.5482.1197

[22] DOLZNIG H, SCHWEIFER N, PURI C, KRAUT N, RETTIG WJ et al. Characterization of cancer stroma markers: in silico analysis of an mRNA expression database for fibroblast activation protein and endosialin. Cancer Immun 2005; 5: 10.

[23] HARDIE DL, BALDWIN MJ, NAYLOR A, HAWORTH OJ, HOU TZ et al. The stromal cell antigen CD248 (endosialin) is expressed on naive CD8+ human T cells and regulates proliferation. Immunology 2011; 133: 288-295 http://dx.doi. org/10.1111/j.1365-2567.2011.03437.x

[24] HRUZ T, LAULE O, SZABO G, WESSENDORP F, BLEULER $S$ et al. Genevestigator v3: a reference expression database for the meta-analysis of transcriptomes. Adv Bioinformatics 2008; 2008: 420747. http://dx.doi.org/10.1155/2008/420747

[25] OHRADANOVA A, GRADIN K, BARATHOVA M, ZATOVICOVA M, HOLOTNAKOVA T et al. Hypoxia upregulates expression of human endosialin gene via hypoxiainducible factor 2. Br J Cancer 2008; 99: 1348-1356. http:// dx.doi.org/10.1038/sj.bjc.6604685

[26] APRELIKOVA O, WOOD M, TACKETT S, CHANDRAMOULI GV, BARRETT JC. Role of ETS transcription factors in the hypoxia-inducible factor- 2 target gene selection. Cancer Res 2006; 66: 5641-5647. http://dx.doi. org/10.1158/0008-5472.CAN-05-3345

[27] SHETA EA, TROUT H, GILDEA JJ, HARDING MA. Theodorescu D. Cell density mediated pericellular hypoxia leads to induction of HIF-1alpha via nitric oxide and Ras/MAP kinase mediated signaling pathways. Oncogene 2001; 20: 7624-7634. http://dx.doi.org/10.1038/sj.onc.1204972

[28] CARTHARIUS K, FRECH K, GROTE K, KLOCKE B, HALTMEIER $M$ et al. MatInspector and beyond: promoter analysis based on transcription factor binding sites. Bioinformatics 2005; 21: 2933-2942. http://dx.doi.org/10.1093/bioinformatics/bti473
[29] GONZALEZ-AMARO R, SANCHEZ-MADRID F. Cell adhesion molecules: selectins and integrins. Crit Rev Immunol 1999; 19: 389-429.

[30] VESTWEBER D, BLANKS JE. Mechanisms that regulate the function of the selectins and their ligands. Physiol Rev 1999; 79: 181-213.

[31] NANDA A, KARIM B, PENG Z, LIU G, QIU W et al. Tumor endothelial marker 1 (Tem1) functions in the growth and progression of abdominal tumors. Proc Natl Acad Sci U S A 2006; 103: 3351-3356. http://dx.doi.org/10.1073/ pnas. 0511306103

[32] TOMKOWICZ B, RYBINSKI K, FOLEY B, EBEL W, KLINE $B$ et al. Interaction of endosialin/TEM1 with extracellular matrix proteins mediates cell adhesion and migration. Proc Natl Acad Sci U S A 2007; 104: 17965-17970. http://dx.doi. org/10.1073/pnas.0705647104

[33] ARMulik A, GENOVE G, Betsholtz C. Pericytes: developmental, physiological, and pathological perspectives, problems, and promises. Developmental cell 2011; 21: 193-215. http://dx.doi.org/10.1016/j.devcel.2011.07.001

[34] TOMKOWICZ B, RYBINSKI K, SEBECK D, SASS P, NICOLAIDES NC et al. Endosialin/TEM-1/CD248 regulates pericyte proliferation through PDGF receptor signaling. Cancer Biol Ther 2010; 9: 908-915. http://dx.doi.org/10.4161/ cbt.9.11.11731

[35] NAYLOR AJ, MCGETTRICK HM, MAYNARD WD, MAY $\mathrm{P}, \mathrm{BARONE} \mathrm{F}$ et al. A differential role for CD248 (Endosialin) in PDGF-mediated skeletal muscle angiogenesis. PloS one 2014; 9: e107146. http://dx.doi.org/10.1371/journal. pone. 0107146

[36] PRIES AR, HOPFNER M, LE NOBLE F, DEWHIRST MW, SECOMB TW. The shunt problem: control of functional shunting in normal and tumour vasculature. Nature Rev Cancer 2010; 10: 587-593. http://dx.doi.org/10.1038/nrc2895

[37] NAYLOR AJ, AZZAM E, SMITH S, CROFT A, POYSER C et al. The mesenchymal stem cell marker CD248 (endosialin) is a negative regulator of bone formation in mice. Arthritis Rheum 2012; 64: 3334-3343. http://dx.doi.org/10.1002/ $\underline{\operatorname{art} .34556}$

[38] MOGLER C, WIELAND M, KONIG C, HU J, RUNGE A et al. Hepatic stellate cell-expressed endosialin balances fibrogenesis and hepatocyte proliferation during liver damage. EMBO Mol Med 2015; 7: 332-338. http://dx.doi.org/10.15252/ emmm.201404246

[39] WILHELM A, ALDRIDGE V, HALDAR D, NAYLOR AJ, WESTON CJ et al. CD248/endosialin critically regulates hepatic stellate cell proliferation during chronic liver injury via a PDGF-regulated mechanism. Gut (2015). http://dx.doi. org/10.1136/gutjnl-2014-308325

[40] KONTSEKOVA S, OHRADANOVA REPIC A, POLCICOVA K, TUOMAALA P, PASTOREK J et al. Novel monoclonal antibodies specific for CTLD-SSC and sialomucin domains of endosialin, a mural cell marker of tumor vasculature. Int J Oncol 2012; 41: 1365-1372.

[41] WU F, STUTZMAN A, MO YY, NOTCH SIGNALING AND ITS ROLE IN BREAST CANCER. Front Biosci 2007; 12: 4370-4383. http://dx.doi.org/10.2741/2394 
[42] BERGERS G, BREKKEN R, MCMAHON G, VU TH, ITOH $\mathrm{T}$ et al. Matrix metalloproteinase- 9 triggers the angiogenic switch during carcinogenesis. Nat Cell Biol 2000; 2: 737-744. http://dx.doi.org/10.1038/35036374

[43] TOTH M, CHVYRKOVA I, BERNARDO MM, HERNANDEZ-BARRANTES S, FRIDMAN R. Pro-MMP-9 activation by the MT1-MMP/MMP-2 axis and MMP-3: role of TIMP-2 and plasma membranes. Biochem Biophys Res Commun 2003; 308: 386-395. http://dx.doi.org/10.1016/S0006-291X(03)01405-0

[44] BENEDITO R, ROCA C, SORENSEN I, ADAMS S, GOSSLER A et al. The Notch ligands Dll4 and Jagged1 have opposing effects on angiogenesis. Cell 2009; 137: 1124-1135. http://dx.doi.org/10.1016/j.cell.2009.03.025

[45] MAIA M, DE VRIESE A, JANSSENS T, MOONS M, VAN LANDUYT $\mathrm{K}$ et al. CD248 and its cytoplasmic domain: a therapeutic target for arthritis. Arthrit Rheumat 2010; 62: 3595-3606. http://dx.doi.org/10.1002/art.27701

[46] VAN DAM S, CRAIG T, DE MAGALHAES JP. GeneFriends: a human RNA-seq-based gene and transcript co-expression database. Nucl Acid Res 2015; 43: D1124-1132. http://dx.doi. org/10.1093/nar/gku1042

[47] NEWMAN AC, NAKATSU MN, CHOU W, GERSHON $\mathrm{PD}$, HUGHES CC. The requirement for fibroblasts in angiogenesis: fibroblast-derived matrix proteins are essential for endothelial cell lumen formation. Mol Biol Cell 2011; 22: 3791-3800. http://dx.doi.org/10.1091/mbc.E11-05-0393

[48] LU P, WEAVER VM, WERB Z. The extracellular matrix: a dynamic niche in cancer progression. The J Cell Biol 2012; 196: 395-406. http://dx.doi.org/10.1083/jcb.201102147
[49] EMING SA, HUBBELL JA. Extracellular matrix in angiogenesis: dynamic structures with translational potential. Experiment Dermatol 2011; 20: 605-613. http://dx.doi. org/10.1111/j.1600-0625.2011.01309.x

[50] CHACKO AM, LI C, NAYAK M, MIKITSH JL, HU J et al. Development of 124I immuno-PET targeting tumor vascular TEM1/endosialin. J Nucl Med 2014; 55: 500-507. http:// dx.doi.org/10.2967/jnumed.113.121905

[51] FACCIPONTE JG, UGEL S, DE SANCTIS F, LI C, WANG L et al. Tumor endothelial marker 1-specific DNA vaccination targets tumor vasculature. J Clin Invest 2014; 124: 1497-1511. http://dx.doi.org/10.1172/JCI67382

[52] KIYOHARA E, DONOVAN N, TAKESHIMA L, HUANG S, WILMOTT JS et al. Endosialin Expression in Metastatic Melanoma Tumor Microenvironment Vasculature: Potential Therapeutic Implications. Cancer Microenv 2015; 8: 111-118. http://dx.doi.org/10.1007/s12307-015-0168-8

[53] ROULEAU C, GIANOLIO DA, SMALE R, ROTH SD, KRUMBHOLZ R et al. Anti-Endosialin Antibody-Drug Conjugate: Potential in Sarcoma and Other Malignancies. Mol Cancer Ther 2015. http://dx.doi.org/10.1158/1535-7163. $\underline{\mathrm{MCT}-15-0312}$

[54] DIAZ LA, JR, COUGHLIN CM, WEIL SC, FISHEL J, GOUNDER MM et al. A first-in-human phase I study of MORAb-004, a monoclonal antibody to endosialin in patients with advanced solid tumors. Clin Cancer Res 2015; 21: 1281-1288. http://dx.doi.org/10.1158/1078-0432.CCR-14$\underline{1829}$ 
Supplemental Table 1. List of selected genes co-expressed with endosialin according to analyses of Genevestigator (A) and Genefriends (B) databases. Numbers correspond to Pearson's correlation coefficients. Description of genes and functions of encoded proteins was adopted from GeneCards ${ }^{\circledR}$, The Human Gene database (www.genecards.org).

List of selected genes co-expressed with endosialin according to analyses of Genevetigator (A) and Genefriends (B) databases, numbers correspond to Pearson's correlation coefficients.

\begin{tabular}{|c|c|c|c|c|}
\hline Gene & A & B & Annotation & Description and/or function \\
\hline PCOLCE & 0.89 & 0.69 & procollagen C-endopeptidase & cleavage of type I procollagen, ECM remodeling \\
\hline ADAMTS2 & 0.83 & 0.70 & $\begin{array}{l}\text { ADAM metallopeptidase with } \\
\text { thrombospondin type } 1 \text { motif } 2 \\
\text { (pro-collagen N-propeptidase) }\end{array}$ & $\begin{array}{l}\text { cleavage of fibrillar procollagens types I, II and V, ECM } \\
\text { remodeling, developmental processes }\end{array}$ \\
\hline COL1A1 & 0.80 & 0.65 & collagen, type I, alpha 1 & fibrillar components of interstitial ECM in connective and \\
\hline COL1A2 & 0.79 & 0.62 & collagen, type I, alpha 2 & tumor tissues and in vascular system \\
\hline COL3A1 & 0.76 & - & collagen, type III, alpha 1 & \\
\hline COL5A1 & 0.77 & - & collagen, type V, alpha 1 & \\
\hline COL12A1 & 0.75 & - & collagen, type XII, alpha 1 & \\
\hline COL6A1 & 0.78 & 0.68 & collagen, type VI, alpha 1 & networking components of ECM, major structural component \\
\hline COL6A2 & 0.83 & 0.70 & collagen, type VI, alpha 2 & of microfibrils / cell adhesion, PDGF binding, FGFR signaling, \\
\hline COL6A3 & 0.79 & 0.59 & collagen, type VI, alpha 3 & \\
\hline FBN1 & 0.75 & - & $\begin{array}{l}\text { fibrillin } 1 \text { (TGF-beta binding } \\
\text { matrix protein) }\end{array}$ & $\begin{array}{l}\text { ECM component / pro-angiogenic, vascular remodeling and } \\
\text { EMT, structural support force, binds TGF-beta and BMP }\end{array}$ \\
\hline EFEMP2 & 0.73 & 0.73 & $\begin{array}{l}\text { EGF-containing fibulin-like } \\
\text { extracellular matrix protein } 2\end{array}$ & $\begin{array}{l}\text { ECM component / elastin fiber formation and connective } \\
\text { tissue development }\end{array}$ \\
\hline FBLN2 & 0.72 & - & fibulin 2 & ECM component / organ development, elastic fiber formation \\
\hline NID2 & 0.71 & - & nidogen 2 (osteonidogen) & $\begin{array}{l}\text { BM component / cell adhesion, binds to collagen I, IV and } \\
\text { laminin }\end{array}$ \\
\hline VASN & 0.71 & 0.65 & vasorin & inhibitor of TGF-beta signaling \\
\hline MFAP5 & 0.71 & - & microfibrillar-associated protein & ECM component / cell attachment to microfibrils \\
\hline EMILIN1 & 0.78 & 0.65 & elastin microfibril interface 1 & $\begin{array}{l}\text { ECM component / anchoring smooth muscle cells to elastic } \\
\text { fibers, vessel assembly }\end{array}$ \\
\hline MXRA8 & 0.83 & 0.76 & matrix-remodeling associated 8 & ECM remodeling / maturation of blood-brain barrier \\
\hline GLT8D2 & 0.78 & - & $\begin{array}{l}\text { glycosyltransferase } 8 \text { domain } \\
\text { containing } 2\end{array}$ & protein glycosylation \\
\hline SERPINH1 & - & 0.59 & $\begin{array}{l}\text { Serpin peptidase inhibitor, clade } \\
\mathrm{H} \text {, member } 1\end{array}$ & collagen chaperone / ECM remodeling \\
\hline LOX & 0.72 & 0.60 & lysyl oxidase & cross-linking of collagens I and IV \\
\hline LOXL1 & 0.80 & - & lysyl oxidase-like 1 & elastin fiber polymerization \\
\hline LOXL2 & 0.68 & 0.61 & lysyl-oxidase-like 2 & cross-linking of collagen / developmental angiogenesis \\
\hline TWIST1 & 0.73 & 0.46 & Twist homolog 1 & TF / cell lineage determination and differentiation \\
\hline TWIST2 & 0.79 & 0.55 & Twist homolog 2 & TF / promotion of EMT, inhibits premature differentiation \\
\hline ANGPTL2 & 0.75 & - & angiopoetin-like 2 & sprouting angiogenesis, vasculogenesis and inflammation \\
\hline MRC2 & 0.74 & 0.58 & mannose receptor, $C$ type 2 & ECM remodeling, degradation of collagen ligands, cancer \\
\hline COPZ2 & 0.74 & 0.66 & $\begin{array}{l}\text { coatomer protein complex, } \\
\text { subunit zeta } 2\end{array}$ & formation of vesicles, retrograde transport Golgi-ER \\
\hline MMP2 & 0.73 & 0.59 & $\begin{array}{l}\text { matrix metalloproteinase } 2 \text { ( } 72 \\
\mathrm{kDa} \text { type IV collagenase) }\end{array}$ & $\begin{array}{l}\text { ECM remodeling, signal transduction, angiogenesis, } \\
\text { metastasis }\end{array}$ \\
\hline MMP14 & - & 0.57 & $\begin{array}{l}\text { matrix metalloproteinase } 14 \\
\text { (membrane-inserted) }\end{array}$ & ECM cleavage, actin reorganization, metastasis \\
\hline TIMP2 & - & 0.66 & $\begin{array}{l}\text { TIMP metallopeptidase } \\
\text { inhibitor } 2\end{array}$ & $\begin{array}{l}\text { inhibition of endothelial cell proliferation, inactivation of } \\
\text { MMPs }\end{array}$ \\
\hline CTSK & 0.70 & - & cathepsin K & ECM degradation, bone remodeling, tumor invasiveness \\
\hline ITGA11 & 0.75 & - & integrin, alpha 11 & collagen receptor \\
\hline IGFBP6 & 0.70 & - & $\begin{array}{l}\text { insulin-like growth factor- } \\
\text { binding protein } 6\end{array}$ & modulation of growth-promoting effects of IGF \\
\hline IGFBP4 & & 0.55 & $\begin{array}{l}\text { insulin-like growth factor- } \\
\text { binding protein } 4\end{array}$ & modulation of growth-promoting effects of IGF \\
\hline TMEM119 & 0.70 & 0.58 & transmembrane protein 119 & cell differentiation \\
\hline TSPAN4 & 0.70 & - & tetraspanin 4 & signal transduction, development, growth, motility \\
\hline ANXA5 & - & 0.56 & Annexin A5 & $\begin{array}{l}\text { calcium-binding, signal transduction, inflammation, growth } \\
\text { and differentiation }\end{array}$ \\
\hline
\end{tabular}


Supplemental Table 1. List of selected genes co-expressed with endosialin according to analyses of Genevestigator (A) and Genefriends (B) databases. Numbers correspond to Pearson's correlation coefficients. Description of genes and functions of encoded proteins was adopted from GeneCards ${ }^{\circledR}$, The Human Gene database (www.genecards.org).

List of selected genes co-expressed with endosialin according to analyses of Genevetigator (A) and Genefriends (B) databases, numbers correspond to Pearson's correlation coefficients.

\begin{tabular}{|c|c|c|c|c|}
\hline Gene & A & B & Annotation & Description and/or function \\
\hline PCOLCE & 0.89 & 0.69 & procollagen C-endopeptidase & cleavage of type I procollagen, ECM remodeling \\
\hline ADAMTS2 & 0.83 & 0.70 & $\begin{array}{l}\text { ADAM metallopeptidase with } \\
\text { thrombospondin type } 1 \text { motif } 2 \\
\text { (pro-collagen N-propeptidase) }\end{array}$ & $\begin{array}{l}\text { cleavage of fibrillar procollagens types I, II and V, ECM } \\
\text { remodeling, developmental processes }\end{array}$ \\
\hline COL1A1 & 0.80 & 0.65 & collagen, type I, alpha 1 & fibrillar components of interstitial ECM in connective and \\
\hline COL1A2 & 0.79 & 0.62 & collagen, type I, alpha 2 & tumor tissues and in vascular system \\
\hline COL3A1 & 0.76 & - & collagen, type III, alpha 1 & \\
\hline COL5A1 & 0.77 & - & collagen, type V, alpha 1 & \\
\hline COL12A1 & 0.75 & - & collagen, type XII, alpha 1 & \\
\hline COL6A1 & 0.78 & 0.68 & collagen, type VI, alpha 1 & networking components of ECM, major structural component \\
\hline COL6A2 & 0.83 & 0.70 & collagen, type VI, alpha 2 & of microfibrils / cell adhesion, PDGF binding, FGFR signaling, \\
\hline COL6A3 & 0.79 & 0.59 & collagen, type VI, alpha 3 & \\
\hline FBN1 & 0.75 & - & $\begin{array}{l}\text { fibrillin } 1 \text { (TGF-beta binding } \\
\text { matrix protein) }\end{array}$ & $\begin{array}{l}\text { ECM component / pro-angiogenic, vascular remodeling and } \\
\text { EMT, structural support force, binds TGF-beta and BMP }\end{array}$ \\
\hline EFEMP2 & 0.73 & 0.73 & $\begin{array}{l}\text { EGF-containing fibulin-like } \\
\text { extracellular matrix protein } 2\end{array}$ & $\begin{array}{l}\text { ECM component / elastin fiber formation and connective } \\
\text { tissue development }\end{array}$ \\
\hline FBLN2 & 0.72 & - & fibulin 2 & ECM component / organ development, elastic fiber formation \\
\hline NID2 & 0.71 & - & nidogen 2 (osteonidogen) & $\begin{array}{l}\text { BM component / cell adhesion, binds to collagen I, IV and } \\
\text { laminin }\end{array}$ \\
\hline VASN & 0.71 & 0.65 & vasorin & inhibitor of TGF-beta signaling \\
\hline MFAP5 & 0.71 & - & microfibrillar-associated protein & ECM component / cell attachment to microfibrils \\
\hline EMILIN1 & 0.78 & 0.65 & elastin microfibril interface 1 & $\begin{array}{l}\text { ECM component / anchoring smooth muscle cells to elastic } \\
\text { fibers, vessel assembly }\end{array}$ \\
\hline MXRA8 & 0.83 & 0.76 & matrix-remodeling associated 8 & ECM remodeling / maturation of blood-brain barrier \\
\hline GLT8D2 & 0.78 & - & $\begin{array}{l}\text { glycosyltransferase } 8 \text { domain } \\
\text { containing } 2\end{array}$ & protein glycosylation \\
\hline SERPINH1 & - & 0.59 & $\begin{array}{l}\text { Serpin peptidase inhibitor, clade } \\
\mathrm{H} \text {, member } 1\end{array}$ & collagen chaperone / ECM remodeling \\
\hline LOX & 0.72 & 0.60 & lysyl oxidase & cross-linking of collagens I and IV \\
\hline LOXL1 & 0.80 & - & lysyl oxidase-like 1 & elastin fiber polymerization \\
\hline LOXL2 & 0.68 & 0.61 & lysyl-oxidase-like 2 & cross-linking of collagen / developmental angiogenesis \\
\hline TWIST1 & 0.73 & 0.46 & Twist homolog 1 & TF / cell lineage determination and differentiation \\
\hline TWIST2 & 0.79 & 0.55 & Twist homolog 2 & TF / promotion of EMT, inhibits premature differentiation \\
\hline ANGPTL2 & 0.75 & - & angiopoetin-like 2 & sprouting angiogenesis, vasculogenesis and inflammation \\
\hline MRC2 & 0.74 & 0.58 & mannose receptor, $C$ type 2 & ECM remodeling, degradation of collagen ligands, cancer \\
\hline COPZ2 & 0.74 & 0.66 & $\begin{array}{l}\text { coatomer protein complex, } \\
\text { subunit zeta } 2\end{array}$ & formation of vesicles, retrograde transport Golgi-ER \\
\hline MMP2 & 0.73 & 0.59 & $\begin{array}{l}\text { matrix metalloproteinase } 2 \text { ( } 72 \\
\mathrm{kDa} \text { type IV collagenase) }\end{array}$ & $\begin{array}{l}\text { ECM remodeling, signal transduction, angiogenesis, } \\
\text { metastasis }\end{array}$ \\
\hline MMP14 & - & 0.57 & $\begin{array}{l}\text { matrix metalloproteinase } 14 \\
\text { (membrane-inserted) }\end{array}$ & ECM cleavage, actin reorganization, metastasis \\
\hline TIMP2 & - & 0.66 & $\begin{array}{l}\text { TIMP metallopeptidase } \\
\text { inhibitor } 2\end{array}$ & $\begin{array}{l}\text { inhibition of endothelial cell proliferation, inactivation of } \\
\text { MMPs }\end{array}$ \\
\hline CTSK & 0.70 & - & cathepsin K & ECM degradation, bone remodeling, tumor invasiveness \\
\hline ITGA11 & 0.75 & - & integrin, alpha 11 & collagen receptor \\
\hline IGFBP6 & 0.70 & - & $\begin{array}{l}\text { insulin-like growth factor- } \\
\text { binding protein } 6\end{array}$ & modulation of growth-promoting effects of IGF \\
\hline IGFBP4 & & 0.55 & $\begin{array}{l}\text { insulin-like growth factor- } \\
\text { binding protein } 4\end{array}$ & modulation of growth-promoting effects of IGF \\
\hline TMEM119 & 0.70 & 0.58 & transmembrane protein 119 & cell differentiation \\
\hline TSPAN4 & 0.70 & - & tetraspanin 4 & signal transduction, development, growth, motility \\
\hline ANXA5 & - & 0.56 & Annexin A5 & $\begin{array}{l}\text { calcium-binding, signal transduction, inflammation, growth } \\
\text { and differentiation }\end{array}$ \\
\hline
\end{tabular}

